\title{
A Systematic Review of Information Sharing and Governments' Response to Detriments
}

\author{
Xiaoqian $\mathrm{Cao}^{1, *, \dagger}$, Boang $\mathrm{Xu}^{2, \dagger}$ \\ 1Cambridge International Exam Centre in Shanghai Experimental Foreign language School, 201210, ShangHai, \\ 200000, China \\ 2Suzhou Foreign Language School, 215000, SuZhou, 215000, China \\ *Corresponding author. Email: guanghua.ren@gecacademy.cn \\ $\dagger$ These authors contributed equally.
}

\begin{abstract}
Throughout human history, natural disasters and virus disasters have always existed. It's always been a human problem to solve. However, with the aggravation of environmental pollution, these are becoming more and more serious. The study emphasizes on information dissemination and means relevant to specific disasters: environmental disasters and Virus attacks pre-warning and measures after an incident. Based on the post-earthquake treatment in Nepal, and the government's response to COVID-19 in the USA, this study presents an in-depth analysis of the impact pathways of transmission and reconstruction and the impact on the public. Literature research will be used in this study. There are two ways to do; what the media do and what the government does. The government uses social media such as TikTok, and Twitter to spread information about the Nepal earthquake and COVID-19. One common example of this would be this. Facebook uses News Feed Perform to direct users to the local health department's website. In the wake of the government's discovery of the panic and social impact of the natural disaster and Coronavirus, the government in Nepal and the donor communities led to the establishment of the Kathmandu Valley Earthquake Risk Management of the Project. Amid the COVID-19 outbreak, governments around the world are calling on people to don masks and take preventive measures, and they are actively advocating people to get vaccinated against the virus. We inform readers of approach used by the government to deal with the earthquake and COVID-19, and we analyzed how the government made better use of the media to deal with problems after these.
\end{abstract}

Keywords: natural disasters, Nepal earthquake, epidemic, COVID-19, actions, media, information di ssemination, measurement

\section{INTRODUCTION}

As technology becomes more advanced,the earth is deteriorating. In recent years, large-scale natural disasters frequently occurs. The world has been hit with a series of big natural disasters, from Hurricane Katrina in the USA, to earthquakes in Haiti and Asia [1]. What's more, it will lead to pandemics. Epidemics are different from natural disasters, which are natural physical or geological forces rather than biological forces. They can occur frequently, such as meningococcal meningitis in the African meningitis belt. However, after natural disasters, epidemics may increase and intensify. Sometimes the situation is not clear. Generally speaking, all kinds of events that endanger human life, property, and existence are called disasters. The government needs to take actions. All the people are conscious of these disasters, and at this time, government departments need to clean up the mess and preserve people's interests. As of 2017, it is claimed that $77 \%$ of Americans own and use smartphones [2]. The adoption of this technology has given unprecedented and immediate access to people for actively generating and producing information.Media accounts are powerful socio-cultural artifacts that both reflect and foster common socio-cultural understanding. This means that the media does not only present objective facts but also communicates cultural and personal attitudes, values, and emotions [3]. Just as Morling and Lamouex approached mediacoverage as a " cultural product"-a manifestation of psychological tendencies-we need to consider the psychological aspects of the coverage [2]. Our study focuses on information dissemination and 
means related to specific disasters: natural disasters and Virus attacks pre-warning and measures after a disaster.

According to literature review, former researches mainly focused on how they respond effectively through the media when natural disasters like tsunami and fires occurred. Generally, they considered about almost everything, but what experts don't consider is how to get people to change the way they read about natural disasters, increasing their awareness of natural disasters. Social media platforms allow information to be framed in mainstream platforms which limit communication. Social media enables news stories to quickly go viral and later can lead to misinterpretations that can cause conflict. Furthermore, we can discover that the media is quick and universal in conveying disaster information. Media can also find the advantages and disadvantages of different governments in the face of disasters. As a result, media helps to find the relationship between the two of them, and to have a deep understanding of actions taken by the government and media.

\section{GOVERNMENT RESPOND TO NATURAL DISASTERS AND VIRUSES THROUGH THE MEDIA}

\subsection{Using social media to propagate information about natural degradation and disasters.}

Nowadays, the earth has become worse. Scientists from the New Jersey Institute of Technology, USA point to an unexpected effect of climate change. They concluded that the earth has become darker, which means the clouds became smaller. As the clouds became that, their ability to reflect light also decreases, amusing the planet to become darker and hotter. Changing climate change means occur of natural disasters such as tsunami, earthquakes, drought. Not only constructions but also the life of residents in this area will be threatened. Many people may become homeless or traumatized due to that. Thus, it's a vital thing for the government to prevent and take positive measures to post-disaster reconstruction. One common way for the government to prevent is to rebuild. The government would use social media to disseminate information. Official social media will help departments directly connect with citizens since today more people are online than ever. Number of Facebook users increases. Users are consistently voicing their opinions on user policy and functionality. Today, more people are online than ever, the SSMR found that an average Australian spends more than 10 hours on Facebook alone per week, while the use of platforms like Twitter and Instagram has rapidly increased. Thus, it is inevitable that government departments, achieve their desired policy objectives, such as the government response to disasters, and use media to increase citizens' awareness of disasters prevention. One example is the earthquake that happened in Nepal [4]. The earthquake in 2015 in Nepal (also known as the Gorkha earthquake) killed nearly 9,000 people and injured nearly $22,000[5,6]$. It was the worst natural disaster to strike Nepal since the 1934 Nepal-Bihar earthquake $[7,8,9]$. Within minutes of the earthquake, the Government of India, via the Indian Armed Forces initiated Operation Maitri (Operation Amity), created humanitarian missions with the primary objective of conducting relief and rescue operations in Nepal [4]. What's more, the local government waterproofed shelters and helped the residents to protect livestock. Moerover, governments also, facilitated training to vulnerable people. However, there are often a lot of viruses and bacteria after floods.

\subsection{Utilizing media for information of COVID-19}

The most common way for the government to advertise the epidemic is by social media currently. To date, social media platforms are necessary for disseminative data throughout the happening of coronavirus 2019 (COVID-19). The Centers for Malady Management and Prevention, the Globe Health Organization (GHO) and alternative health care organizations are frequently posting steerage across several platforms. Groups utilized social media platforms to share coronavirus information with local citizens. Facebook is using the news feed perform to direct users to the websites of native health authorities. Google Scholar has highlighted leading medical journals and alternative sites. Twitter and other social media sites are equally informed people who search (accounting for misspellings) for coronavirus-related content to reliable resources. Health care organizations, clinicians, and social media influencers ought to additionally actively direct online traffic to sure sources. It should even be time for social media platforms to use banners, pop-ups, and other tools to inform local people of hand laundry and social distancing.

However, this approach will increase the unreliability of the site and leads to the spread of rumors. Social media has additionally become a platform for spreading each rumor and deliberating misinformation. Plenty of perpetrators are deploying sites e.g. Facebook, Twitter, YouTube, and WhatsApp to form a way of panic and confusion. Relative to this, 'infodemic' is a word means an over-abundance of information - some correct and a few not-that makes it arduous for individuals to seek out trustworthy sources and reliable guidance. Social media as a diagnostic tool and referral system, it should be used to circularize reliable information. If an immunogen becomes available, constant platforms may be used to address challenges related to vaccine hesitancy. Health systems could become weak as testing becomes a lot on 
the market and as more gently sick however involved people look for care; social media platforms are well poised to alter users to remotely assess symptoms and confirm their most applicable course of action. The Facebook Preventive Health tool provides individuals with vetted tips regarding preventive health recommendations (e.g. heart disease, cancer screening). Therefore, users have the choice to share the tool and their regular checking with their network. This might be changed to help people to approach resources for COVID-19 testing. For those whose test results are positive for COVID-19, the platform could alter users to tell their contacts regarding the potential exposure and the way to follow up for testing[10].

\section{GOVERNMENTS RESPOND TO NATURALDISASTERS AND VIRUSES THROUGH REAL ACTION}

\subsection{Practically response to the Nepal earthquake}

Since the occurring of the Nepal earthquake, the meaning of devastation is fully revealed in the experience of this quake, which has disrupted urban and rural physical settings. The first few days saw many people flee of the country in panic in selfish disregard for the local partners with whom they had shared so much. Many countries rescued their people leaving others to despair. The sight of some fleeting and others rushing in makes one ponder the wisdom of the action itself; So what did the local government do? The rescue of devastated people from under the rubble in the aftermath of the Earthquake was a spontaneous effort of local people and authorities working without any proper instructions. The Red Cross and local volunteers were much appreciated for help in the rescue of several lives from the rubble. It was not surprising that those at the top floors escaped the death traps. The prompt relief by the international and the local communities was what brought the quake-ravaged populace to a safe mode of refuge in the temporary shelters like tents, tarpaulins, and tunnels of corrugated sheets. This helped society, in turn, to achieve some resilience to the earthquake by ensuring that post-earthquake epidemics like cholera, typhoid, swine flu, dysentery, and diarrhea do not occur. What's more, it is not the first time happened in this country. The potential for earthquakes in Nepal was already realized immediately after the 1988 Earthquake of Dharan and Rajbiraj which killed 722 people in Nepal and India, injured 12,000, and 450,000 left homeless. The best part of this quake was the triggering of awareness within the Government in Nepal and the donor communities leading to the establishment of the Kathmandu Valley Earthquake Risk Management Project, 1997 [10]. After the Nepal Earthquake in 2015, the Nepal Earthquake Housing Reconstruction
Association (IDA)is working to help more than 330,000 homeowners from poor rural households in 32 affected districts of Nepal rebuild their homes using disaster-resilient construction techniques and materials; the project has also introduced a culture of resilient construction in the country through policies, strengthening institutional capacity, and training engineers and masons. They took an owner-driven approach to housing reconstruction- homeowners themselves make any decisions related to the reconstruction of their homes. The project provides technical assistance to ensure that homeowners know about resilient reconstruction methods that can withstand natural disasters to ensure that the reconstructed houses comply with technical reconstruction specifications and guidelines. This technology has been successfully embedded throughout the project to ensure efficiency. The Earthquake Housing Reconstruction Project, which focused on promoting resilient construction practices, empowering women, leaving no one behind, promoting good governance, and supporting overall economic development, has helped achieve the following results between 2015-2020: As of September 2020, 211,985 resilient houses (out of the project target of 335,700) have been reconstructed with full/partial housing grant support from IDA credits. Similarly, 3,766 houses have been reconstructed with support from a Multi-Donor Trust Fund (MDTF) grant; Moreover, the government offered many welfare benefits to appease the victims. More than 70 percent of project beneficiaries opened bank accounts to receive project grants. Most had never had a bank account before and of these accounts, 30 percent were opened by women [11]. This shows that reconstruction has given women more rights to work.

\subsection{Practically response to COVID-19}

On the other hand, to reduce the transmission of the virus and rebuild the unstable society, means are addressed for the epidemic. The United Nations organized "solidarity flights" , which were chartered planes that flew millions of masks, goggles, gloves, robes, and other supplies. On April 14, the United Nations dispatched a chartered Ethiopian Airlines flight from Addis Ababa to countries in need, carrying COVID-19 equipment. Separating sick people from high-risk groups, relocating them from houses where they might live alone or with extended families to unoccupied homes, or taking over buildings previously used for other purposes, such as learning centers, is a contentious tactic being tried by health officials. The elderly and those with pre-existing health issues that make them prone to COVID-19, as well as the homeless, are among the target group. Many governments around the world have turned to the police to ensure that people stay at home and to punish those who do not. Violations of the blockade in India, for 
example, might result in a year in prison. According to NPR, other countries in the country face strange punishments such as writing "I'm sorry" 500 times. It's time to switch gears and tackle the coronavirus. Kenya's textile sector has shifted its focus to the production of masks and safety gear. The Kitai Prefecture Textile Center (KICOTEC) has altered its focus from producing white and school uniforms for chefs to masks and scrubs for medical personnel. Kenya's state-owned oil business is currently producing hand sanitizer and claims to be giving it around for free. Denel, a state-owned missile manufacturer in South Africa, has been designing and manufacturing ventilators as well as converting armored trucks into ambulances. The government has created the National Ventilator Project, which challenges businesses to produce 10,000 ventilators using locally available materials by the end of June. A similar initiative is underway in Nigeria, where the government has indicated that it will collaborate with automobile manufacturers to develop locally manufactured ventilators.

WHO Director-General Tedros Adhanom Ghebreyesus proclaimed the launch of the worldwide COVID-19 vaccination strategy, attending to inject forty percentage of the world's population against COVID-19 by the top of the year and seventy percent by the center of next year. The strategy implies a minimum of eleven billion doses of COVID-19 immunizing agent, and with a mean of nearly 1.5 billion doses created globally each month. There's enough vaccine to attain this strategy if it's distributed fairly. By the end of September, over half a dozen billion doses of COVID-19 vaccine had been administered globally, in line with who statistics[13,14].

\section{CONCLUSION}

Based on this systematic review, we can find that there are several links between the way for dealing with natural disasters and pandemics. This paper studies the government's response to the virus and natural disasters, namely COVID-19 and the Nepal earthquake. On the one hand, it is found that the use of media to convey disaster information is quick and universal. On the other hand, the advantages and disadvantages of the US government and the Nepal government in dealing with disasters are analyzed.

We can see that governments of different countries such as Nepal, the USA,India, Kenya, South Africa,Nigeria have used the media to disseminate information to ensure that citizens attach importance to disasters and disaster prevention.In practice, after the Nepal earthquake, the local government built waterproof shelters. The Red Cross and volunteers helped train vulnerable groups, built earthquake-resistant houses, introduced reconstruction methods and technologies, and restored water supplies everywhere. Kenya increased production of face masks, provided free hand sanitizer. The United Nations quarantined patients according to their severity. South Africa converted trucks into ambulances to provide ventilators and vaccinations.

Above all, this paper focuses on the government's handling of natural disasters and virus hazards through the media and other ways. We inform readers of approach used by the government to deal with the earthquake and Covid-19. We analyzed how the government made better use of the media to deal with problems occurring after earthquakes and Covid-19. We suggest people to keep a kind and friendly attitude towards the global disasters, and to come up with better solutions in this frame of mind. Not only must the government do something, but the company must also enhance the work efficiency. In addition, the government needs to adjust and improve countermeasures, improve legal provisions and reduce disaster losses.

\section{REFERENCES}

[1] Pew Research Center. Mobile Fact Sheet[online]. retrieved (2018), fromhttps://www.pewresearch. org/internet/fact-sheet/mobile/.

[2] Morling, B., \& Lamoreaux, M. (2008). Measurin g Culture Outside the Head: A Meta-Analysisof I ndividualism-Collectivism in Cultural Products.Pe ronality and SocialP. sychology Review,12(3), 1 99-221. https:/d.oi.org/10.1177/108886830831826 0 .

[3] Markus, H. R., Uchida, Y., Omoregie,H.,Townsen d, S. S., \& Kitayama, S.(2006). Going for the go 1d. Models of agency in Japanese and American contexts. Psychological science, 17(2),103-112. h ttps://doi.org/10.1111/j.1467-9280.2006.01672.x.

[4] Sidmartinbio.org, users question. [online] retrieve d (2021). Fromhttps://cn.bing.com/search?q=Sidm artinbio.org\%2C+users + question. $\&$ go $=$ Search \&qs $=\mathrm{n} \&$ form $=\mathrm{QBRE} \& \mathrm{sp}-1 \& \mathrm{pq}=$ sidmartinbio.org $\% 2 \mathrm{C}$ +users+question. \&. $\quad \mathrm{sc}=1-33 \& \mathrm{sk}=\& \mathrm{cvid}=\mathrm{D} 15 \mathrm{~F} 33$ 90C76F4248B1B31F34189E6D93.

[5] Sindhupalchowk (2021) reports two aftershocks o f Gorkha quake. Nepal press.

[6] Chidanand Rajghatta (2015)'Is this the Big Hima layan Quake we feared?' The Times of India.

[7] 'What 1934 Told Nepal to Expect About the Ne xt Big Quake'. (2015).

[8] 'Timeline (2015): Nepal 2015 to 1934, theworst quake disasters in the last 80 years.' Retrieved.

[9] The New Indian Express (2015)'Nepal earthquak e: Eerie reminder of 1934 tragedy'. 
[10] Xiaohui Chen andZiyi.Qiu (2020) COVID-19: G overnment interventionsand the economy | VOX, CEPR Policy Portal (voxeu.org).

[11] Journal of the Latin-American association of qua lity control, pathology and recovery of constructi on [online] retrieved (2020). from https://revistaal conpat.org/index.php/RA/article/view/176/346.

[12] The World Bank. (2020) Post-Earthquake Recons truction in Nepal: Rebuilding Lives, One Home at a Time, fromhttps://www.worldbank.org/en/res ults/2020/09/29/post-earthquake-reconstruction-innepal-rebuilding-lives-one-home-at-a-time.

[13] World Health Organization Launches Global Ne w Crown vaccination strategy[online] (2021)https: //baijiahao.baidu.com/s?id=1713001124510453001. $\& w f r=$ spider \&for $=$

[14] Chen, X and Z Qiu (2020), “Scenario analy sis of non-pharmaceutical interventions on global COVID-19 transmissions", Covid Economics: Ve tted and Real-Time Papers, CEP 